\title{
Human triglyceride-rich lipoproteins impair glucose metabolism and insulin signalling in L6 skeletal muscle cells independently of non-esterified fatty acid levels
}

Received: 12 July 2004 / Accepted: 15 November 2004 / Published online: 4 March 2005

(C) Springer-Verlag 2005

\begin{abstract}
Aims/hypothesis: Elevated fasting and postprandial plasma levels of triglyceride-rich lipoproteins (TGRLs), i.e. VLDL/remnants and chylomicrons/remnants, are a characteristic feature of insulin resistance and are considered a consequence of this state. The aim of this study was to investigate whether intact TGRL particles are capable of inducing insulin resistance. Methods: We studied the effect of highly purified TGRLs on glycogen synthesis, glycogen synthase activity, glucose uptake, insulin signalling and intramyocellular lipid (IMCL) content using fully differentiated L6 skeletal muscle cells. Results: Incubation with TGRLs diminished insulin-stimulated glycogen synthesis, glycogen synthase activity, glucose uptake and insulin-stimulated phosphorylation of Akt and glycogen synthase kinase 3 . Insulin-stimulated tyrosine phosphorylation of IRS-1, and IRS-1- and IRS-2-associated phosphatidylinositol 3-kinase (PI3K) activity were not impaired by TGRLs, suggesting that these steps were not involved in the lipoprotein-induced effects on glucose metabolism. The overall observed effects were time- and dose-dependent and paralleled IMCL accumulation. NEFA concentration in the incubation media did not increase in the presence of TGRLs indicating that the effects observed were solely due to intact lipoprotein particles. Moreover, co-incubation of TGRLs with orlistat, a potent active-site inhibitor of various lipases,
\end{abstract}

Duality of interest All authors declare that there is no duality of interest with a company/organisation that would financially benefit from the publication of the data in our manuscript

M. T. Pedrini $(\bowtie) \cdot$ M. Kranebitter $\cdot$ A. Niederwanger

S. Kaser · J. Engl $\cdot$ J. R. Patsch

Clinical Department of Internal Medicine,

Medical University of Innsbruck,

Anichstrasse 35,

6020 Innsbruck, Austria

e-mail: michael.pedrini@uibk.ac.at

Tel.: +43-512-50423326

Fax: $+43-512-50428539$

P. Debbage $\cdot$ L. A. Huber

Department of Histology and Molecular Cell Biology,

Medical University of Innsbruck,

Innsbruck, Austria did not alter TGRL-induced effects, whereas co-incubation with receptor-associated protein (RAP), which inhibits interaction of TGRL particles with members of the LDL receptor family, reversed the TGRL-induced effects on glycogen synthesis and insulin signalling. Conclusions/ interpretation: Our data suggest that the accumulation of TGRLs in the blood stream of insulin-resistant patients may not only be a consequence of insulin resistance but could also be a cause for it.

Keywords Glucose metabolism · Insulin resistance · Insulin signalling $\cdot$ Non-esterified fatty acids $\cdot$ Receptorassociated protein - Skeletal muscle cells - Triglyceriderich lipoproteins

Abbreviations GSK-3: glycogen synthase kinase 3 . IMCL: intramyocellular lipid - LDH: lactate dehydrogenase - LPL: lipoprotein lipase - PI3K: phosphatidylinositol 3-kinase - RAP: receptor-associated protein $\cdot S_{\mathrm{f}}$ : Svedberg flotation rate $\cdot$ TGRL:

triglyceride-rich lipoprotein

\section{Introduction}

Insulin resistance represents a major metabolic abnormality in the pathogenesis of type 2 diabetes, one of the leading causes of mortality and invalidity. The factors responsible for the development of insulin resistance and type 2 diabetes have yet to be elucidated. Three lipid abnormalities are characteristic of insulin resistance and type 2 diabetes, i.e. high plasma levels of NEFAs, dyslipidaemia and pronounced postprandial lipaemia. A fourth lipid abnormality suggested to be a determinant of insulin resistance is the increase of intramyocellular lipid (IMCL) content in skeletal muscle [1-4].

Various experimental settings have been used to study the effects of NEFAs on insulin sensitivity. In a number of human and animal studies, plasma NEFA levels were raised by intravenous infusion of lipid emulsions together with heparin to stimulate lipoprotein lipase (LPL) activity. 
The rise in plasma levels of NEFAs has been shown to induce insulin resistance [5-8]. In line with these studies, it has been demonstrated that CD36 knockout mice have improved insulin sensitivity in muscle, implying that fatty acid flux into the cells plays a critical role in insulin resistance [9]. Several studies investigated the effect of various NEFAs on insulin signalling and glucose metabolism in vitro using different cell lines [10-13]. Taking together the results of all these studies, elevated NEFA levels have been convincingly shown to play a causal role in the pathogenesis of insulin resistance. In addition, several studies have demonstrated that NEFAs are also capable of inducing beta cell dysfunction [14-17], the other major metabolic abnormality of type 2 diabetes.

Despite the wealth of data on the contribution of NEFAs to the development of insulin resistance and beta cell dysfunction, very little is known about the role of native lipoproteins in the development of these two processes. Elevated fasting and postprandial plasma levels of triglyceride-rich lipoproteins (TGRLs), i.e. VLDL/remnants and chylomicrons/remnants, decreased HDL levels, and small dense LDL particles, are characteristic of the dyslipidaemia of insulin resistance and type 2 diabetes. According to a widely held view, these characteristic changes in lipoprotein pattern are a consequence of insulin resistance and type 2 diabetes. However, a recent study using mouse pancreatic islets and a transformed insulin-secreting beta cell line demonstrated that purified TGRL and LDL particles may induce insulin-secreting beta cell dysfunction, indicating that the changes in plasma lipoproteins characteristic of type 2 diabetes are not only a consequence but also a cause of this disease [18]. To our knowledge, however, nothing is known as to whether intact lipoprotein particles are also capable of inducing insulin resistance. Intact lipoproteins including TGRL particles have been shown to be able to enter the subendothelial space by whole lipoprotein particle uptake [19-25] and in this way can come into contact with cell surfaces of various peripheral tissues.

Therefore, the rationale for this study was to investigate whether intact TGRL particles are capable of inducing insulin resistance in skeletal muscle cells, a principal site of peripheral insulin resistance.

\section{Materials and methods}

Materials The L6 rat skeletal muscle cell line was obtained from ATCC (Manassas, VA, USA); $\alpha$-MEM, amyloglucosidase and the L- $\alpha$-PI3 standard were purchased from Sigma (St. Louis, MO, USA), FCS from PromoCell (Heidelberg, Germany) and fatty acid-/insulin-free BSA from Valeant Pharmaceuticals (Bryan, OH, USA). Sepharose $2 \mathrm{~B},\left[{ }^{14} \mathrm{C}\right]-\mathrm{UDPG}$ and the ECL kit were purchased from Amersham Biosciences (Buckinghamshire, UK), deoxy$\left[{ }^{3} \mathrm{H}\right]$-glucose and $\left[{ }^{32} \mathrm{P}\right]$-ATP from PerkinElmer (Boston, MA, USA), phosphatidylinositol from Avanti Polar Lipids (Alabaster, AL, USA) and the 4-15\% linear-gradient mini gels from Biorad (Hercules, CA, USA). Anti-IRS-1, antiIRS-2, anti-phosphotyrosine-4G10 and anti-GSK-3 (anti- glycogen synthase kinase 3 ) antibodies were obtained from Upstate (Charlottesville, VA, USA); anti-phospho-GSK-3 $\alpha$ / $\beta$-ser21/9, anti-phospho-Akt-ser473 and anti-Akt antibodies were from Cell Signaling Technology (Beverly, MA, USA). GAPDH antibody was purchased from Abcam (Cambridge, UK). The RAP fusion protein was obtained from Progen (Heidelberg, Germany) and orlistat (Xenical) from Roche (Hertfordshire, UK). Lipoprotein fractionation gels were obtained from LaboMed (Waldkirch, Germany).

Cell culture Stock cells of the L6 rat skeletal muscle cell line were stored frozen in liquid nitrogen and a fresh vial of cells was thawed for every experiment. Cells were cultured in $\alpha$-MEM containing 10\% FCS to confluency and then switched to the same media containing $2 \%$ FCS. Cells, cultured in 60-mm culture dishes or chamber slides (for oil red $\mathrm{O}$ staining), were used up to the fifth passage, and experiments were performed with fully differentiated myotubes 12-14 days post-confluency.

Lipoprotein isolation TGRLs, customarily defined as lipoproteins with a Svedberg flotation rate $\left(S_{f}\right)$ higher than 20 , were isolated from young healthy individuals in the postprandial state from blood withdrawn $4 \mathrm{~h}$ after ingestion of a standardised fatty meal [26]. Informed consent was obtained from all donors. To prevent bacterial growth, $10 \mathrm{mmol} / \mathrm{N} \mathrm{NaN}_{3}$ was added to all solutions for the following centrifugation steps. For isolation of lipoproteins, entire plasma was subjected to an ultracentrifugation step in a Beckman type 42.1 rotor at $40,000 \times \mathrm{g}$ at a plasma density of $1.006 \mathrm{~kg} / \mathrm{l}$ for $16 \mathrm{~h}$ at $15^{\circ} \mathrm{C}$. The top fraction of the tubes containing TGRLs was then subjected to a zonal ultracentrifugation procedure for analytically defining and preparatively isolating TGRL particle subfractions [27]. A density gradient linear with volume ranging from 1.00 to $1.15 \mathrm{~kg} / \mathrm{l}$ was formed and ultracentrifugation was performed at $42,000 \times \mathrm{g}$ for $45 \mathrm{~min}$ at $15^{\circ} \mathrm{C}$ [28]. Two fractions were obtained by pooling appropriate volume contents of the rotor (Beckman TI-14): firstly, lipoprotein fractions with an $\mathrm{S}_{\mathrm{f}}$ higher than 200 corresponding mainly to chylomicrons/remnants; and secondly, a fraction with an $\mathrm{S}_{\mathrm{f}}$ of between 20 and 200 corresponding mainly to VLDL/ remnants. The zonally isolated lipoproteins were concentrated by pressure filtration using Amicon cells and subsequently purified further by gel filtration using Sepharose 2B with PBS as an eluent buffer [29]. Purity of TGRL fractions was confirmed by gel electrophoresis using lipoprotein fractionation gels. The purified lipoproteins were stored in the dark at $4^{\circ} \mathrm{C}$ under nitrogen for up to 2 weeks after preparation. The lipoprotein concentration in the media was chosen to correspond to a triglyceride concentration of $456 \mu \mathrm{mol} / 1$.

Incubation experiments One day prior to the experiments, the media was replaced by serum-free $\alpha$-MEM containing $0.25 \%$ fatty acid- and insulin-free BSA, and cells were incubated in the presence or absence of purified TGRLs. Immediately prior to insulin stimulation, cells were washed with the above starvation media. Cells were incubated with- 
out or with insulin for various lengths of time, lysed and analysed for glycogen content, glycogen synthase activity, glucose uptake and insulin signalling as detailed below.

Controls for cytotoxicity and cell viability To test whether TGRLs have toxic effects on L6 cells, we measured lactate dehydrogenase $(\mathrm{LDH})$ in the incubation media at the beginning and end of all lipoprotein incubations. We did not observe any rise in LDH concentration upon TGRL incubation. In addition, possible TGRL-induced apoptosis was excluded by DAPI staining of the cells. Cell viability after treatment with TGRLs was assessed by trypan blue exclusion. Viability was found to be equal to that in non-TGRLtreated cells. For all these assays, $\mathrm{H}_{2} \mathrm{O}_{2}$ or BSA-deprived cell culture media were used as positive controls.

Glycogen content After incubation of cells without or with $100 \mathrm{nmol} / 1$ insulin for $3 \mathrm{~h}$ at $37^{\circ} \mathrm{C}$, we determined glycogen content by a modification of the method described by Keppler and Decker [30]. Briefly, after washing four times with ice-cold PBS, cells were collected in $0.6 \mathrm{~mol} / 1$ $\mathrm{HClO}_{4}$ and homogenised by sonification in ice water. Aliquots of the homogenate were neutralised with $1 \mathrm{~mol} / 1$ $\mathrm{KHCO}_{3}$ and incubated with $10 \mathrm{~g} / 1$ amyloglucosidase in $0.2 \mathrm{~mol} / 1$ acetate buffer $(\mathrm{pH} 4.8)$ for $2 \mathrm{~h}$ at $40^{\circ} \mathrm{C}$. The reaction was stopped by addition of chilled $2 \mathrm{~mol} / 1 \mathrm{HClO}_{4}$ and centrifugation at $14,000 \mathrm{~g}$ at $4^{\circ} \mathrm{C}$ for $10 \mathrm{~min}$. Glucose concentration was determined using a Cobas MIRA analyser from Roche. Glycogen content was expressed as nmol glucose/mg protein.

For the experiments with receptor-associated protein (RAP), this protein was added at a concentration of $1 \mu \mathrm{mol} / 1$ to the incubation media 15 min prior to the addition of TGRLs and then co-incubated with TGRLs for $3 \mathrm{~h}$.

Orlistat was prepared as previously described [31] and co-incubated at a concentration of $250 \mu \mathrm{g} / 1$ with TGRLs for $3 \mathrm{~h}$.

Glycogen synthase activity For determining glycogen synthase activity by a modification of the method described by Thomas et al. [32], cells were incubated without or with $100 \mathrm{nmol} / \mathrm{l}$ insulin for $30 \mathrm{~min}$ at $37^{\circ} \mathrm{C}$, washed with a buffer containing $50 \mathrm{mmol} / \mathrm{l}$ Tris- $\mathrm{HCl} \mathrm{pH} 7.6$ and $100 \mathrm{mmol} / \mathrm{l} \mathrm{KF}$ and collected in the above buffer containing $30 \%$ glycerol, $1 \mathrm{mmol} / \mathrm{l} \mathrm{EDTA}, 10 \mathrm{mg} / \mathrm{l}$ aprotinin, $10 \mathrm{mg} / \mathrm{l}$ leupeptin and $1 \mathrm{mmol} / \mathrm{l} \mathrm{PMSF}$. After sonification and centrifugation, aliquots of the supernatant were added to the reaction mix containing $50 \mathrm{mmol} / \mathrm{l} \mathrm{Tris}-\mathrm{HCl} \mathrm{pH} \mathrm{7.6,} 20 \mathrm{mmol} / \mathrm{l}$ EDTA, $25 \mathrm{mmol} / 1 \mathrm{KF}, 10 \mathrm{~g} / \mathrm{l}$ glycogen, $7.2 \mathrm{mmol} / \mathrm{l} \mathrm{UDPG}$ and $1.85 \mathrm{kBq}\left[{ }^{14} \mathrm{C}\right]-U D P G$ in the presence of $0.3 \mathrm{mmol} / 1 \mathrm{glu}-$ cose 6-phosphate and $6.7 \mathrm{mmol} / 1$ glucose 6-phosphate respectively for $1 \mathrm{~h}$ at $30^{\circ} \mathrm{C}$. The reaction was terminated by spotting the mixture on filter papers that were extensively washed with ice-cold $70 \%$ ethanol overnight and air dried. Then, radioactivity was counted using a Beckman scintillation counter, and enzyme activity was expressed as a percentage of the glucose 6-phosphate-independent form.
2-Deoxy-D-glucose uptake After starvation, cells were incubated without or with $1 \mu \mathrm{mol} / 1$ insulin for $1 \mathrm{~h}$ at $37^{\circ} \mathrm{C}$, washed with HBS (20 mmol/1 HEPES pH 7.4, $140 \mathrm{mmol} / 1$ $\left.\mathrm{NaCl}, 2.5 \mathrm{mmol} / 1 \mathrm{MgSO}_{4}, 1 \mathrm{mmol} / 1 \mathrm{CaCl}_{2}, 5 \mathrm{mmol} / \mathrm{KCl}\right)$ and then incubated with HBS-RM (HBS containing $10 \mu \mathrm{mol} / 1$ deoxyglucose and $37 \mathrm{MBq} / 1$ deoxy- $\left[{ }^{3} \mathrm{H}\right]$-glucose for $10 \mathrm{~min}$ at room temperature. After washing cells with ice-cold $\mathrm{NaCl}$ $0.9 \%$, cells were lysed in $0.05 \mathrm{~mol} / 1 \mathrm{NaOH}$ and radioactivity was counted using a Beckman scintillation counter. Glucose uptake was expressed as pmol deoxyglucose per min per mg protein. Cytochalasin B at $10 \mu \mathrm{mol} / 1$ was used to estimate carrier-independent glucose uptake.

Virtually all cultured skeletal muscle cell lines including L6 cells were found to have low levels of GLUT4 gene expression [33]. Therefore, insulin at a concentration of $1 \mu \mathrm{mol} / 1$ was chosen for this experiment to achieve more pronounced effects on glucose uptake.

Western blot analysis After incubation without or with $100 \mathrm{nmol} / 1$ insulin for $5 \mathrm{~min}$, cells were washed with PBS and solubilised in lysis buffer $(50 \mathrm{mmol} / \mathrm{l}$ HEPES, $\mathrm{pH} 7.5$, $1 \%$ Triton X-100, $150 \mathrm{mmol} / 1 \mathrm{NaCl}, 10 \mathrm{mmol} / \mathrm{l}$ EDTA, $10 \%$ glycerol, $10 \mathrm{mg} / 1$ trypsin inhibitor, $1 \mathrm{mmol} / 1 \mathrm{Na}_{3} \mathrm{VO}_{4}$, $1 \mathrm{mmol} / \mathrm{l} \mathrm{PMSF}, 5 \mathrm{mg} / 1$ pepstatin $\mathrm{A}, 10 \mathrm{mg} / 1$ aprotinin, $10 \mathrm{mg} / \mathrm{l}$ leupeptin, $10 \mathrm{mmol} / \mathrm{l} \mathrm{NaF}$ and $10 \mathrm{nmol} / \mathrm{l}$ sodium pyrophosphate). After incubation on ice for $30 \mathrm{~min}$, samples were centrifuged at $10,000 \times \mathrm{g}$ for $5 \mathrm{~min}$ at $4{ }^{\circ} \mathrm{C}$ and the protein content of the supernatant was determined according to the method of Bradford. An aliquot was taken for direct blotting, and the remaining supernatant was used for immunoprecipitation with an anti-IRS-1- and anti-phosphotyrosine antibody respectively overnight at $4^{\circ} \mathrm{C}$. The immune complexes were collected on protein A-agarose during $2 \mathrm{~h}$ of incubation at $4^{\circ} \mathrm{C}$. The beads were washed four times with lysis buffer including $0.1 \%$ instead of $1 \%$ Triton X-100 and boiled for $5 \mathrm{~min}$ in Laemmli buffer. For direct blotting, Laemmli buffer was added to the aliquot of the detergent extract. The solubilised proteins were resolved by SDS-PAGE on $4-15 \%$ linear-gradient mini gels and subjected to immunoblotting using respective antibodies. Loading control was performed using an antibody against GAPDH. For these experiments, the same blot was stripped several times with stripping buffer $(100 \mathrm{mmol} / \mathrm{l}$ 2-mercaptoethanol, $2 \% \mathrm{SDS}, 62.5 \mathrm{mmol} / 1 \mathrm{Tris} / \mathrm{HCl}, \mathrm{pH}$ 6.7) at $70^{\circ} \mathrm{C}$ for $30 \mathrm{~min}$ and reprobed with respective antibodies. Upon incubation with secondary antibodies, immunoreactive bands were detected by enhanced chemiluminescence according to the manufacturer's instructions using Biorad's Fluor S Max imager. Intensity of various bands was expressed as $n$-fold stimulation of condition in the absence of insulin and TGRLs.

IRS-1- and IRS-2-associated phosphatidylinositol 3-kinase activity For this purpose, cells were incubated without or with $100 \mathrm{nmol} / 1$ insulin for $10 \mathrm{~min}$, washed three times with buffer 1 (20 mmol/1 Tris-HCl, pH 7.4, 137 mmol/1 NaCl, $1 \mathrm{mmol} / 1 \mathrm{CaCl}_{2}, 1 \mathrm{mmol} / 1 \mathrm{MgCl}_{2}$ and $1 \mathrm{mmol} / 1 \mathrm{Na}_{3} \mathrm{VO}_{4}$ ) 
and then lysed in buffer 1 containing 1\% NP-40, $1 \mathrm{mmol} / 1$ PMSF, $2 \mathrm{mg} / \mathrm{l}$ leupeptin, $20 \mathrm{mmol} / \mathrm{l}$ sodium pyrophosphate and $50 \mathrm{mmol} / 1 \mathrm{NaF}$. After centrifugation at $14,000 \times \mathrm{g}$ for $10 \mathrm{~min}$ at $4^{\circ} \mathrm{C}$, the supernatant was immunoprecipitated using an anti-IRS-1 antibody and anti-IRS-2 antibody respectively for $2 \mathrm{~h}$ at $4^{\circ} \mathrm{C}$. Immunoprecipitates were washed three times with buffer 1 containing $1 \% \mathrm{NP}-40,1 \mathrm{mmol} / 1$ PMSF, $2 \mathrm{mg} / \mathrm{l}$ leupeptin, $20 \mathrm{mmol} / \mathrm{l}$ sodium pyrophosphate and $50 \mathrm{mmol} / \mathrm{l} \mathrm{NaF}$ and then washed five times with buffer 2 (25 mmol/1 MOPS, pH 7.3, $5 \mathrm{mmol} / 1 \mathrm{MgCl}_{2}, 1 \mathrm{mmol} / 1$ EGTA, $1 \mathrm{mmol} / 1 \mathrm{Na}_{3} \mathrm{VO}_{4}, 1 \mathrm{mmol} / 1 \mathrm{PMSF}, 2 \mathrm{mg} / 1$ leupeptin, $20 \mathrm{mmol} / 1$ sodium pyrophosphate and $50 \mathrm{mmol} / 1 \mathrm{NaF}$ ). The immunoprecipitate was then resuspended in $50 \mu$ l buffer 2 and heated to $37^{\circ} \mathrm{C}$ in a heating block. To start the reaction, $10 \mu \mathrm{l}$ of $0.4 \mathrm{mg} / \mathrm{l}$ sonicated phosphatidylinositol and $20 \mu \mathrm{l}$ of ATP mix (buffer 2 containing $60 \mu \mathrm{mol} / 1 \mathrm{ATP}$ and $925 \mathrm{kBq}$ $\left.{ }^{32} \mathrm{P}\right]$-ATP) were added. After $10 \mathrm{~min}$ at $37^{\circ} \mathrm{C}$, the reaction was stopped by the addition of $37 \% \mathrm{HCl} /$ methanol $(1: 1, \mathrm{v} / \mathrm{v})$. Lipids were extracted with chloroform and the organic phase was removed and applied to silica gel thin layer chromatography plates. The plates were developed in chloroform/methanol/water/ammonia $(60 / 47 / 11.3 / 2, \mathrm{v} / \mathrm{v})$ and the PI3-product was identified by its comigration with an L- $\alpha$ PI3-standard and quantified on a Packard Cyclone phosphoimager. Wortmannin $(100 \mathrm{nmol} / \mathrm{l})$ was used as a negative control. Intensity of various dots was expressed as $n$-fold stimulation of condition in the absence of insulin and TGRLs.

NEFA determination NEFA levels in the cell culture media were determined in the absence of TGRLs and at the beginning and end of all TGRL incubations using a commercial kit from Wako (Neuss, Germany) with the Cobas MIRA system.

Determination of intramyocellular lipid content Cells were grown in chamber slides, starved overnight and incubated in the presence or absence of TGRLs as described above. Cells were fixed in $3.7 \%$ formaline for $30 \mathrm{~min}$ and excess of formaline was removed with tap water. Subsequently, cells were permeabilised using $0.3 \%$ Tween 20 for $1 \mathrm{~min}$ followed by three washes with tap water. Oil red O staining was carried out according to Koopman [34]. Imaging was performed on a laser scanning microscope (Axiovert 200M/LSM 510, Carl Zeiss) with a Texas red excitation filter at $543 \mathrm{~nm}$ and an emission filter (LP 590, Carl Zeiss) at $590 \mathrm{~nm}$. Pictures were preprocessed in MatLab (Mathworks) using an edge-finding algorithm to define the borders of lipid droplets [35]. The area of lipid droplets/ cytoplasmic area was then analysed with QuantityOne (Biorad).

Statistical analysis Two-way ANOVA was performed for the factors insulin and TGRLs. Post-hoc comparisons were made using Fisher's least significant difference method. For experiments in which results were expressed as $n$-fold stimulation over basal, $t$-tests were used: the one-sample $t$-test was used for comparisons to the condition in the absence of insulin and TGRLs, since this reference condition was set to 1 and therefore has the standard deviation
0 . The unpaired $t$-test was used for the remaining comparisons. For $t$-tests, significance levels were corrected using the Bonferroni procedure. For calculations of IMCL content in Fig. 7a, logarithmic transformation of the data was performed to achieve approximately normal distribution. All values were expressed as means \pm SEM and statistical significance was accepted as $p$ being less than 0.05 .

\section{Results}

Reduction of glycogen synthesis, glycogen synthase activity and glucose transport by TGRLs Glycogen synthesis, a sensitive parameter of insulin sensitivity [36], was studied in the presence or absence of TGRLs in a number of pilot experiments. First, we performed a series of dose-response experiments using TGRLs with a $S_{f}$ higher than 200 , defined in the "Materials and methods" section. We added this fraction to the incubation mixture for $3 \mathrm{~h}$ at triglyceride concentrations of $0,114,228$ and $456 \mu \mathrm{mol} / 1$ respectively. As shown in Fig. 1, there was a progressive reduction of insulin-induced glycogen synthesis with increasing doses of TGRLs, with $456 \mu \mathrm{mol} / 1$ triglyceride reducing glycogen synthesis by $80 \%$. Hence, a dose of $456 \mu \mathrm{mol} / 1$ lipoprotein triglyceride was chosen for all following experiments.

Next, we studied the effect of the TGRL fractions with an $S_{\mathrm{f}}$ higher than 200 on glycogen synthesis as a function of incubation time. In the absence of lipoproteins, the wellknown stimulatory effect of insulin on glycogen synthesis was seen (Fig. 2a, two bars on the left). Presence of TGRLs in the incubation mixture had no significant effects on basal glycogen synthesis but reduced the insulin effects over time resulting in an overall progressive reduction in the insulin-induced effects over basal (Fig. 2a).

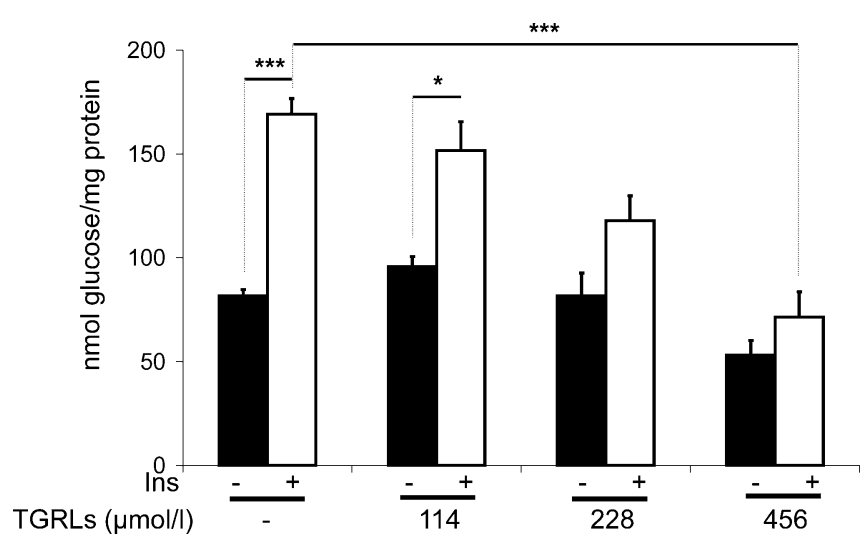

Fig. 1 Reduction of glycogen synthesis by increasing TGRL concentrations. L6 cells were incubated in the absence or presence of increasing concentrations of TGRLs with an $\mathrm{S}_{\mathrm{f}}$ higher than 200 for $3 \mathrm{~h}$, subsequently incubated without or with $100 \mathrm{nmol} / 1$ insulin for $3 \mathrm{~h}$ and analysed for glycogen content. TGRL concentrations corresponded to triglyceride concentrations of $0,114,228$ and $456 \mu \mathrm{mol} / 1$ incubation media. Bars represent the means \pm SEM for four experiments and significant differences are indicated as $* P<0.05$, $* * * P<0.001$ (two-way ANOVA, Fisher's least significant difference method). Ins, insulin 


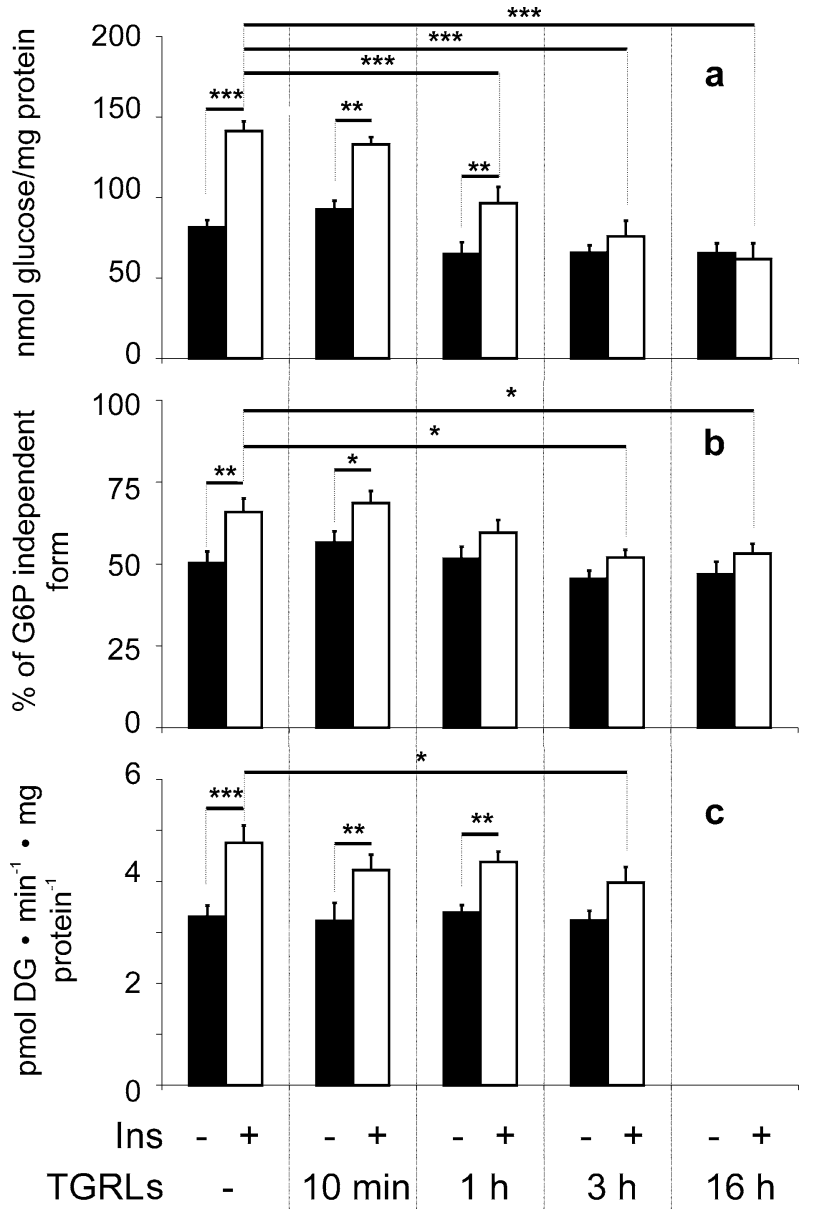

Fig. 2 Reduction of glycogen synthesis, glycogen synthase activity and glucose uptake by TGRLs over time. L6 cells were incubated in the absence or presence of TGRLs with an $\mathrm{S}_{\mathrm{f}}$ higher than 200 (456 $\mu \mathrm{mol} / 1$ triglyceride) for indicated time periods, subsequently incubated without or with insulin and analysed for glycogen content (a), glycogen synthase activity (b) and glucose uptake (c), as detailed under "Materials and methods". Bars represent the means \pm SEM for four to five independent experiments performed in duplicate and significant differences are indicated as $* P<0.05, * * P<0.01$, $* * * P<0.001$ (two-way ANOVA, Fisher's least significant difference method). G6P, glucose 6-phosphate; $D G$, deoxyglucose; Ins, insulin

In accordance with the TGRL-induced effects on glycogen synthesis, glycogen synthase activity showed virtually no changes in the basal state and a progressive reduction of insulin effects over time upon incubation with TGRLs with an $\mathrm{S}_{\mathrm{f}}$ higher than 200 (Fig. 2b). For glucose uptake, a similar pattern of changes upon incubation with TGRLs with an $\mathrm{S}_{\mathrm{f}}$ higher 200 was observed (Fig. 2c).

In parallel experiments, we also studied the denser fraction of TGRLs, as defined in the "Materials and methods" section, containing the lipoproteins with an $\mathrm{S}_{\mathrm{f}}$ of between 20 and 200 and compared its effects on glycogen synthesis, glycogen synthase activity and glucose uptake with the fraction with an $\mathrm{S}_{\mathrm{f}}$ higher than 200 . The TGRL with an $\mathrm{S}_{\mathrm{f}}$ of between 20 and 200 showed comparable effects (data not shown).

Because of the virtual identity of the two TGRL fractions with an $\mathrm{S}_{\mathrm{f}}$ higher than 200 and an $\mathrm{S}_{\mathrm{f}}$ of between 20 and 200 on glycogen synthesis, glycogen synthase activity and glucose uptake, for the subsequent experiments on the underlying mechanism(s), only one of the two lipoprotein fractions, namely the $\mathrm{S}_{\mathrm{f}}$ higher than 200 fraction, was used.

Effects of TGRLs on insulin signalling To answer the question of whether insulin signalling is impaired in a similar fashion to glycogen synthesis, glycogen synthase activity and glucose uptake by TGRLs, we studied several insulin signalling steps that are viewed as important for the regulation of glucose metabolism.

First, we examined IRS-1 tyrosine phosphorylation, regarded as a major proximal step in the activation of downstream insulin signalling [37]. In the absence of lipoproteins, the well-known stimulation of IRS-1 phosphorylation by insulin was seen. The insulin-stimulated tyrosine phosphorylation of IRS-1 showed no significant changes upon TGRL incubation (Fig. 3a, b). Next, we examined the levels of the alpha p85 subunit of PI3K in phosphotyrosine immunoprecipitates. As shown in Fig. 4, insulin induced a

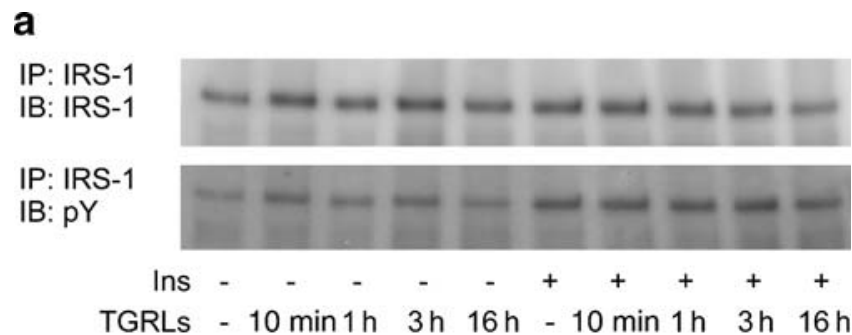

b

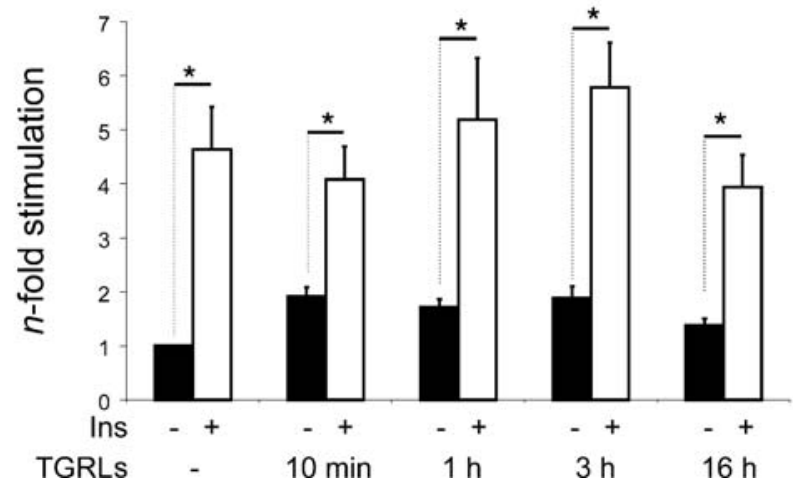

Fig. 3 Effect of TGRLs on IRS-1 tyrosine phosphorylation. Cells were incubated in the absence or presence of TGRLs with an $S_{S}$ higher than 200 (456 $\mu \mathrm{mol} / 1$ triglyceride) for indicated time periods, subsequently incubated without or with $100 \mathrm{nmol} / 1$ insulin for 5 min and solubilised in lysis buffer as described in "Materials and methods". Lysates were subjected to immunoprecipitation $(I P)$ with an antibody to IRS- 1 followed by SDS-PAGE. Immunoblotting (IB) was performed with an antibody to IRS-1 (top panel) and phosphotyrosine $(p Y)$ (bottom panel) (a). The bar graph shows the quantification of tyrosine-phosphorylated IRS-1 (b). Bars represent the means \pm SEM for five independent experiments performed in duplicates and significant differences are indicated as $* P<0.05$ (onesample $t$-test for comparisons to condition in the absence of insulin and TGRLs, unpaired $t$-test for remaining comparisons, Bonferroni correction). Ins, insulin 
marked increase in alpha p85 levels co-immunoprecipitated with tyrosine-phosphorylated proteins. TGRL incubation had no effect on alpha p85 levels in phosphotyrosine precipitates (Fig. 4a, bottom panel, Fig. 4b) and on the expression of alpha p85 (Fig. 4a, top panel). In accordance, both IRS-1associated PI3K activity (Fig. 5a) and IRS-2-associated PI3K activity (Fig. 5b), suggested to be important for insulin-induced translocation of GLUT-4 and thus for glucose transport [38], showed no changes with TGRL incubation.

To determine whether more distal steps in the insulin signalling cascade were affected by TGRLs, we next assessed the phosphorylation of Akt at serine 473. In contrast to IRS-1 tyrosine phosphorylation and IRS-1- IRS-2-associated PI3K activity, a progressive decrease in insulininduced phosphorylation over time was observed, resulting in an overall decrease in the insulin effects over basal (Fig. 6a). Activated Akt has been shown to phosphorylate GSK-3 alpha

a

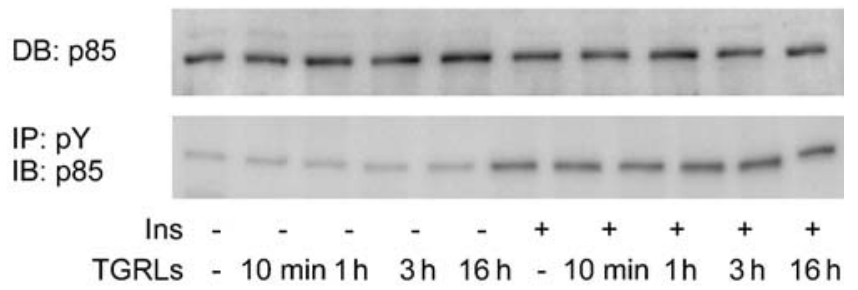

b

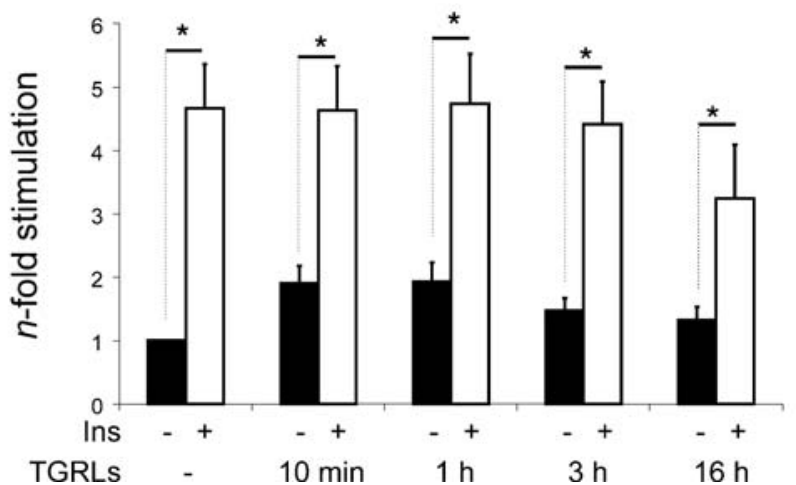

Fig. 4 Effect of TGRLs on the expression of alpha p85 of PI3K and on alpha p85 levels in anti-phosphotyrosine immunoprecipitates. Cells were incubated in the absence or presence of TGRLs with an $\mathrm{S}_{\mathrm{f}}$ higher than $200(456 \mu \mathrm{mol} / 1$ triglyceride) for indicated time periods, subsequently incubated without or with $100 \mathrm{nmol} / \mathrm{l}$ insulin for $5 \mathrm{~min}$ and solubilised in lysis buffer as described in "Materials and methods". An aliquot of the lysates was subjected to SDSPAGE for direct blotting $(D B)$ with an antibody to alpha p85 of PI3K ( 85 ) (top panel), and the remaining lysate was used for immunoprecipitation with an antibody to phosphotyrosine $(p Y)$ followed by immunoblotting with an antibody to alpha p85 of PI3K (bottom panel) (a). The bar graph shows the quantification of alpha p85 associated with tyrosine-phosphorylated proteins (b). Bars represent the means \pm SEM for three independent experiments performed in duplicate and significant differences are indicated as * $P<0.05$ (one-sample $t$-test for comparisons to condition in the absence of insulin and TGRLs, unpaired $t$-test for remaining comparisons, Bonferroni correction). Ins, insulin a
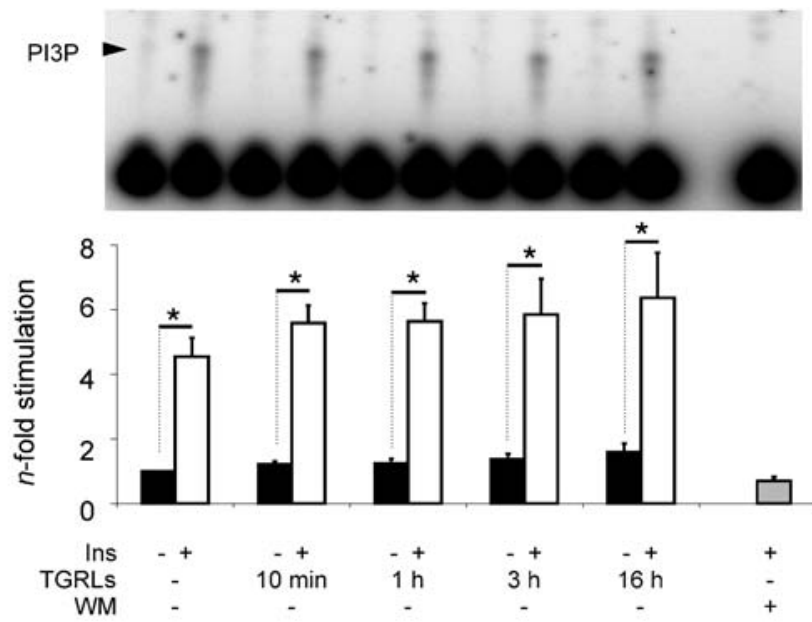

b

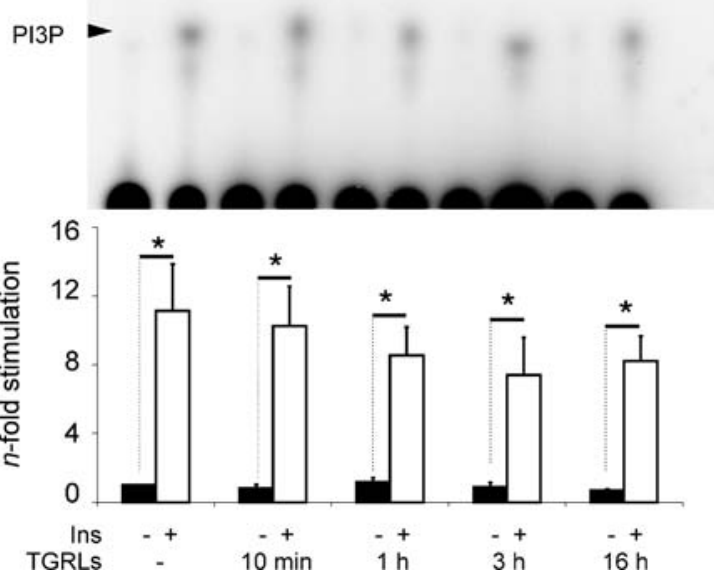

Fig. 5 Effect of TGRLs on IRS-1-and IRS-2-associated PI3K activity. Cells were incubated in the absence or presence of TGRLs with an $\mathrm{S}_{\mathrm{f}}$ higher than $200(456 \mu \mathrm{mol} / 1$ triglyceride) for indicated time periods, subsequently incubated without or with $100 \mathrm{nmol} / \mathrm{l}$ insulin for $10 \mathrm{~min}$ and solubilised in lysis buffer. After immunoprecipitation with an antibody to IRS-1 and IRS-2, IRS-1-associated PI3K activity (a) and IRS-2-associated PI3K activity (b) were determined as described under "Materials and methods". Lipid extracts from assays were subjected to thin layer chromatography and phosphorimaging. Bars represent the means \pm SEM of five independent experiments performed in duplicate and significant differences are indicated as ${ }^{*} P<0.05$ (one-sample $t$-test for comparisons to condition in the absence of insulin and TGRLs, unpaired $t$-test for remaining comparisons, Bonferroni correction). Ins, insulin; PI3P, phosphatidylinositol 3-phosphate; $W M$, wortmannin $(100 \mathrm{nmol} / 1)$

at serine 21 and GSK-3 beta at serine 9 [39]. Phosphorylated GSK-3 exhibits reduced inhibitory activity towards glycogen synthase, thus increasing glycogen synthesis [40]. TGRLs showed similar effects on both the alpha isoform (Fig. 6b) and the beta isoform (Fig. 6c) of GSK-3. In agreement with the changes noted for Akt phosphorylation, TGRL induced a reduction of insulin-stimulated phosphorylation of GSK-3 over time.

For all blotting experiments, controls were performed to estimate the abundance of the respective signalling molecules. These control experiments indicated that the differences in the extent of phosphorylation of the signalling 
a
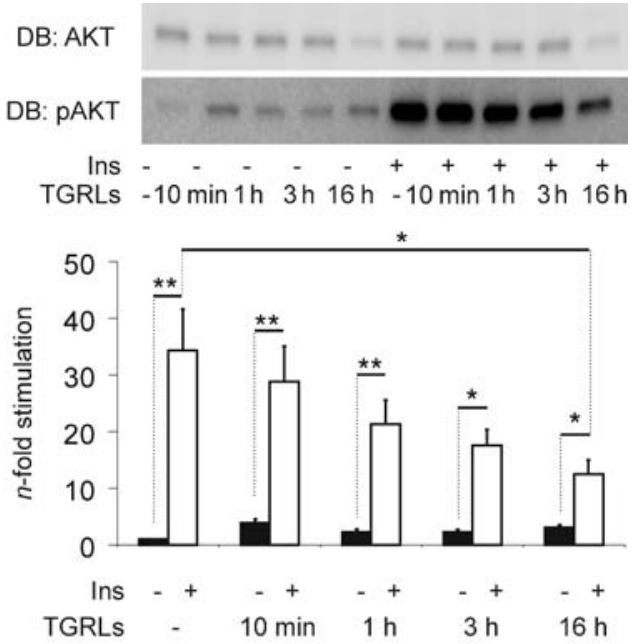

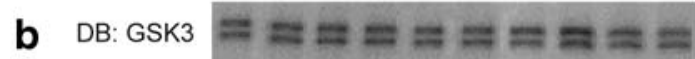

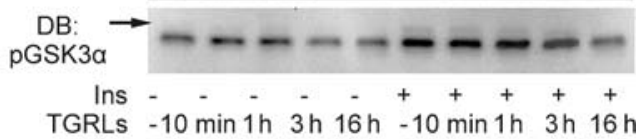

TGRLs $-10 \min 1 \mathrm{~h} \quad 3 \mathrm{~h} 16 \mathrm{~h}-10 \min 1 \mathrm{~h} \quad 3 \mathrm{~h} 16 \mathrm{~h}$
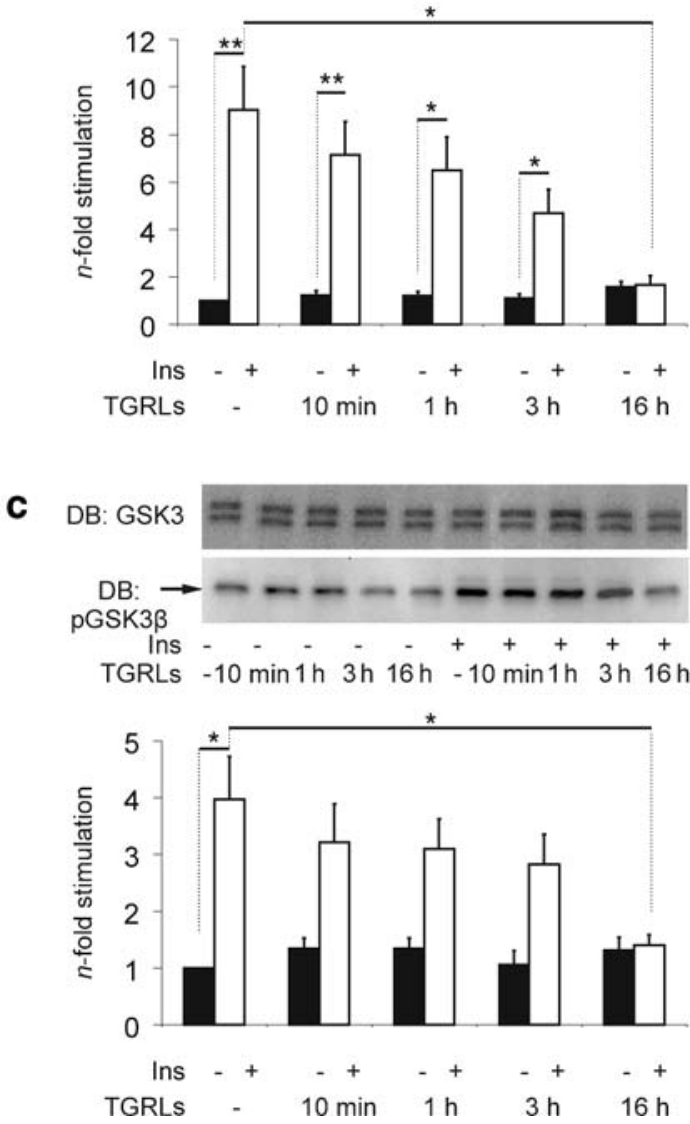

Fig. 6 Effect of TGRLs on Akt- and GSK-3 phosphorylation. Cells were incubated in the absence or presence of TGRLs with an $S_{f}$ higher than $200(456 \mu \mathrm{mol} / 1$ triglyceride $)$ for indicated time periods, subsequently incubated without or with $100 \mathrm{nmol} / 1$ insulin for $5 \mathrm{~min}$ and solubilised in lysis buffer as described under "Materials and methods". Lysates were subjected to SDS-PAGE and, subsequently, direct blotting $(D B)$ was performed with an antibody to Akt and phospho-Akt ( $p A k t)$ (a) and an antibody to GSK-3 and phosphoGSK $-3 \alpha / \beta$ ( $p G S K 3$ ). In $\mathbf{b}$ phosphorylation of GSK-3 $\alpha$ is shown and in $\mathbf{c}$ phosphorylation of GSK-3 $\beta$ is shown. The bar graphs show the quantification of the phosphorylated forms of Akt and GSK-3. Bars represent the means \pm SEM of five independent experiments performed in duplicate and significant differences are indicated as $* P<0.05, * * P<0.01$ (one-sample $t$-test for comparisons to condition in the absence of insulin and TGRLs, unpaired $t$-test for remaining comparisons, Bonferroni correction). Ins, insulin
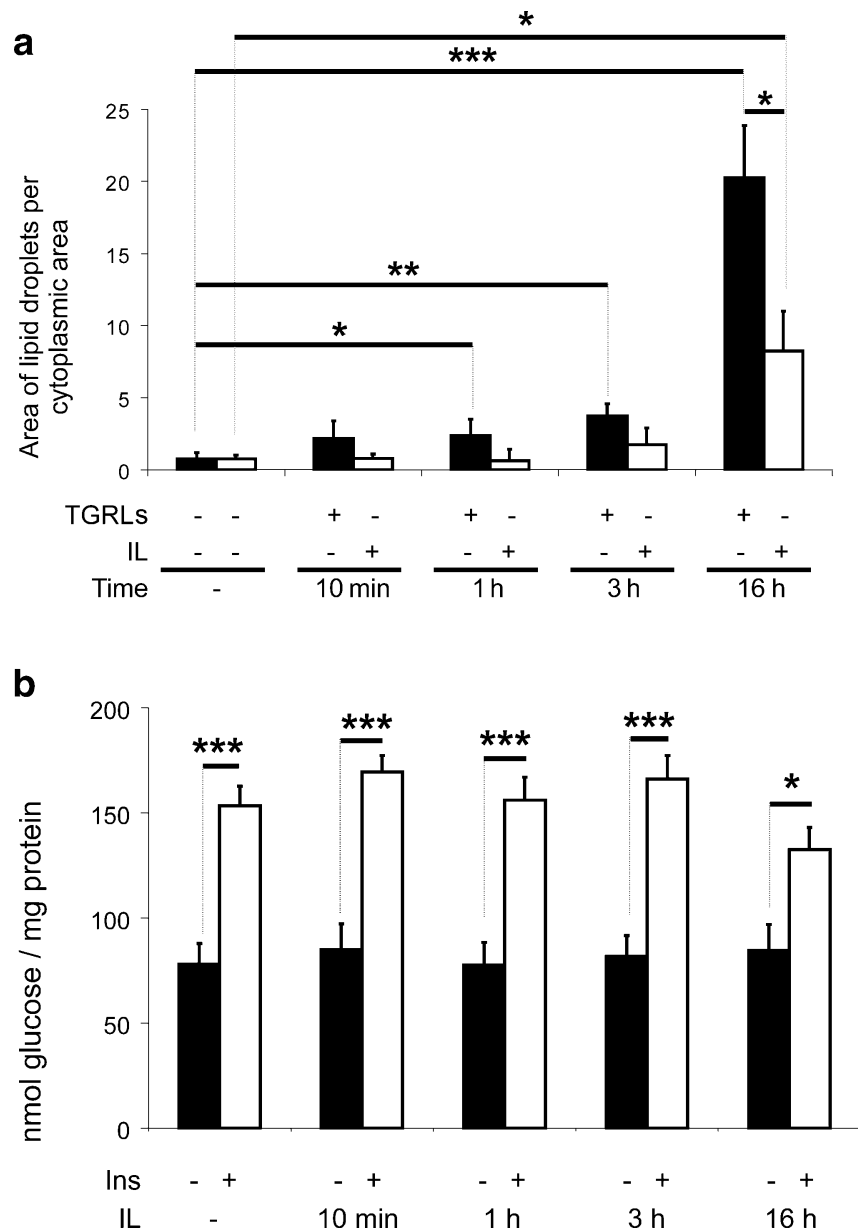

Fig. 7 Effect of TGRLs and Intralipid on IMCL content and of Intralipid on glycogen synthesis in L6 myotubes. For analysis of the IMCL content, L6 cells were incubated in the absence or presence of TGRLs with an $\mathrm{S}_{\mathrm{f}}$ higher than $200(456 \mu \mathrm{mol} / 1$ triglyceride) and Intralipid (456 $\mu \mathrm{mol} / 1$ triglyceride) for various lengths of time, i.e. $10 \mathrm{~min}, 1 \mathrm{~h}, 3 \mathrm{~h}$ and $16 \mathrm{~h}$. After fixation of cells in formaline and permeabilisation with Tween 20, intracellular lipid droplets were stained with oil red $\mathrm{O}$ and detected by laser scan microscopy. Area of lipid droplets was calculated as detailed in the "Materials and methods" section. Analysis of glycogen synthesis was described in Fig. 2a. Area of lipid droplets per cytoplasmic area upon TGRL and Intralipid incubations (a). Effect of Intralipid incubation on glycogen synthesis (b). Bars represent the means \pm SEM for five independent experiments performed in duplicates and significant differences are indicated as $* P<0.05, * * P<0.01, * * * P<0.001$ (twoway ANOVA, Fisher's least significant difference method; in a logarithmic transformation of the data was performed). $I L$, Intralipid 
a

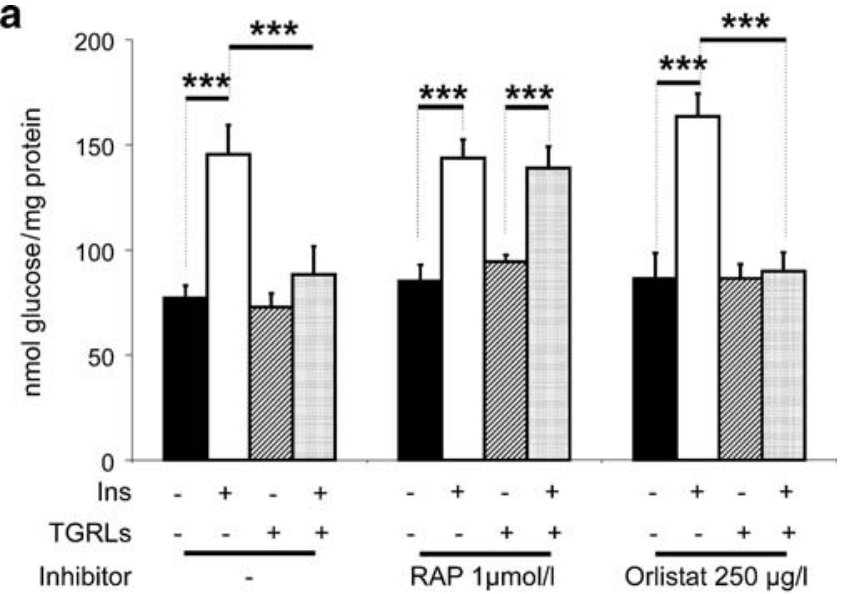

b

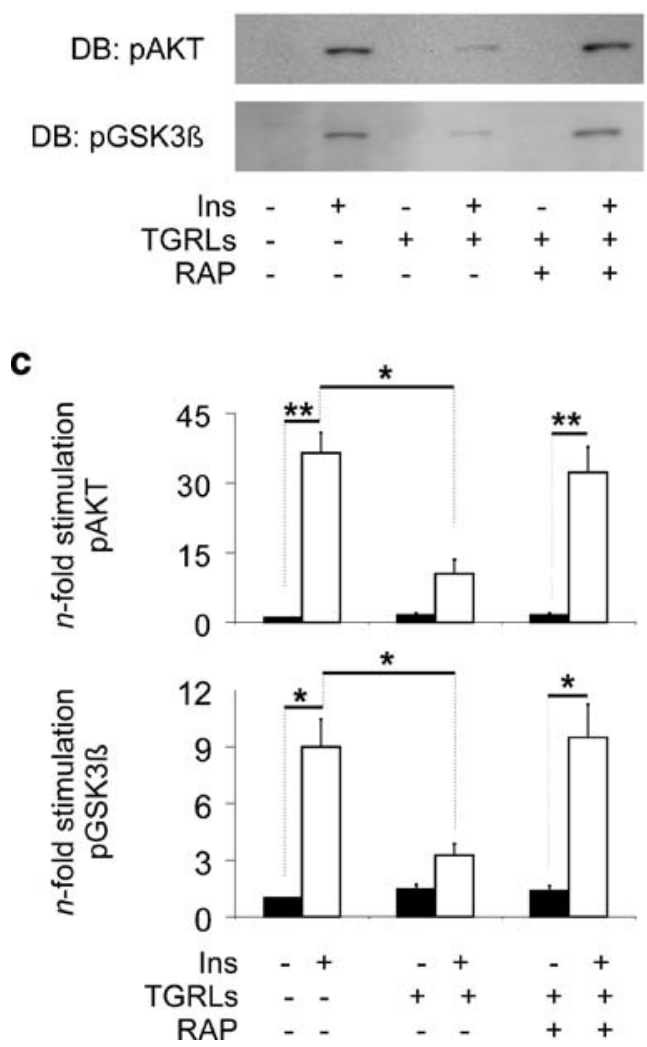

proteins observed were not due to changes in their protein content.

Increase of intramyocellular lipid content by TGRLs To study whether the changes in glucose metabolism and insulin signalling are accompanied by an increase in IMCL content, L6 cells were incubated with TGRLs for $10 \mathrm{~min}$, $1 \mathrm{~h}, 3 \mathrm{~h}$ and $16 \mathrm{~h}$. After staining IMCLs with oil red O, cells were scanned by laser scan microscopy to determine the area occupied by intracellular lipid droplets per cytoplasmic area. As shown in Fig. 7a (black bars), the IMCLs increased progressively over time by TGRL incubation,
Fig. 8 Effect of RAP and orlistat on TGRL-induced alterations. L6 cells were incubated in the absence or presence of TGRLs with an $\mathrm{S}_{\mathrm{f}}$ higher than 200 (456 $\mu \mathrm{mol} / \mathrm{l}$ triglyceride) for $3 \mathrm{~h}$, subsequently incubated without or with $100 \mathrm{nmol} / \mathrm{l}$ insulin for $3 \mathrm{~h}$ and analysed for glycogen content (a). TGRL incubation was performed in the absence or presence of RAP and orlistat. To study the effect of RAP on TGRL-induced alterations in the phosphorylation of Akt and GSK-3 (b), L6 cells were incubated in the absence or presence of RAP and TGRLs with an $\mathrm{S}_{\mathrm{f}}$ higher than 200 (456 $\mu \mathrm{mol} / 1$ triglyceride) for $3 \mathrm{~h}$, and subsequently incubated without or with $100 \mathrm{nmol} / \mathrm{l}$ insulin for $5 \mathrm{~min}$. Direct blotting was performed with antibodies to phosphoAkt $(p A k t)$ and phospho-GSK-3 ( $p G S K-3)$. The bar graph shows the quantification of Akt- and GSK-3 phosphorylation (c). Bars represent the means \pm SEM for three independent experiments performed in duplicate and significant differences are indicated as $* P<0.05$, $* * P<0.01, * * * P<0.001$. For each data set of inhibitors (no inhibitor, RAP, orlistat) in (a), two-way ANOVA with Fisher's least significant difference method was used. For quantification of Akt- and GSK-3 phosphorylation in (c), one sample $t$-test was used for comparisons to condition in the absence of insulin and TGRLs and the unpaired $t$-test for all remaining comparisons. Ins, insulin; $R A P$, receptor-associated protein

such that after $16 \mathrm{~h}$ IMCL content represented about $20 \%$ of the whole cytoplasmic area.

Specificity of the observed effects To answer the question of whether the observed effects are lipoprotein specific or whether they are also induced by triglyceride not assembled in native lipoprotein particles, we replaced TGRLs by Intralipid. Intralipid was subjected to gel filtration as described in the "Materials and methods" section, and the fraction containing the triglyceride micelles was selected and added to incubation mixtures at a triglyceride concentration of $456 \mu \mathrm{mol} / 1$, as used for lipoproteins. In contrast to what was observed with TGRLs (Fig. 2a), no effect on insulin-stimulated glycogen synthesis was seen after $10 \mathrm{~min}$, $1 \mathrm{~h}$ and $3 \mathrm{~h}$. Only after $16 \mathrm{~h}$ of incubation with Intralipid micelles was insulin-stimulated glycogen content decreased by about $30 \%$ (Fig. $7 b$ ).

We next studied whether the effect of Intralipid on glycogen synthesis is related to IMCL content. There was little, if any, IMCL accumulation over $3 \mathrm{~h}$, but after $16 \mathrm{~h}$ a pronounced rise in IMCL content, paralleling closely the reduction in glycogen synthesis, was apparent (Fig. 7a, white bars).

NEFA levels in the incubation media and the effect of orlistat on TGRL-induced reduction of glycogen synthesis. To exclude the possibility of NEFAs rising in the incubation media as a result of lipoprotein triglyceride hydrolysis, we determined the NEFA concentration in the incubation media at the beginning and end of all lipoprotein incubations and compared these concentrations with the one in the absence of TGRLs. We found no increase of NEFA levels in the presence of lipoproteins during all incubations. Furthermore, the concentration of NEFAs in the TGRLcontaining incubation media was equal to the one in the media with no TGRLs present.

To confirm that possible triglyceride hydrolysis with resulting NEFA release is not responsible for the observed 
effects of TGRLs, we co-incubated TGRLs with the potent lipase inhibitor orlistat at $250 \mu \mathrm{g} / \mathrm{l}$ for $3 \mathrm{~h}$ and studied the TGRL-induced effect on glycogen synthesis. This concentration of orlistat has been previously shown to completely inhibit the activity of $8 \mathrm{ng} / \mathrm{ml} \mathrm{LPL} \mathrm{[41],} \mathrm{which} \mathrm{we}$ confirmed using a cell-free system (data not shown). As shown in Fig. 8a, orlistat did not alter the effect of TGRLs on glycogen synthesis, indicating that possible hydrolysis of lipoprotein triglyceride does not contribute to the effects induced by TGRLs.

Reversal of TGRL-induced effects by receptor-associated protein To investigate whether the TGRL-induced effects were receptor mediated, we co-incubated TGRLs with a RAP known to block binding of respective ligands to receptors of the LDL receptor family [42]. Of the observed TGRL-induced effects we first studied the one on glycogen synthesis. Receptor mediation would result in restoring insulin-induced glycogen synthesis. RAP at a concentration of $1 \mu \mathrm{mol} / 1$ was added to the incubation media 15 min prior to the addition of TGRLs and then co-incubated with TGRLs for $3 \mathrm{~h}$. As shown in Fig. 8a, RAP reversed the TGRL-induced reduction of glycogen synthesis. Next, we tested whether RAP may also protect against the TGRL-induced signalling defects noted for Akt and GSK-3. As shown in Fig. 8b, RAP almost completely reversed the observed reduction in Akt- and GSK-3-phosphorylation induced by TGRLs.

\section{Discussion}

Insulin resistance and elevated plasma levels of TGRLs are strongly associated with each other, whereby a potential cause-effect relationship is uncertain. The data presented here strongly point to TGRLs as a potential cause of insulin resistance not appreciated to date.

Virtually everything studied, including glycogen synthesis, glycogen synthase activity, glucose uptake and IMCLs supports this view in that internally consistent effects of TGRLs on these processes were observed. These effects of TGRLs were accompanied in a very compatible fashion by their effects on Akt- and GSK-3 phosphorylation. Our observations on GSK-3, we believe, deserve a special comment. The well-known insulin-induced GSK-3 phosphorylation was reduced by TGRLs. This finding is consistent with the reduction of glycogen synthase activity by TGRLs, since diminished insulin-induced GSK-3 phosphorylation is known to result in an increase of inhibitory activity towards glycogen synthase [40].

A rather unexpected result was the one on IRS-1 tyrosine phosphorylation and PI3K activity, where TGRLs showed no effects. Whatever the significance of this result may be, it is not necessarily an internal inconsistency with our observation on the TGRL-induced reduction of Akt phosphorylation because there are a number of reports showing that activation of PI3K and Akt may not be tightly coupled $[43,44]$. In one study investigating the effect of palmitate on $\mathrm{C} 2 \mathrm{C} 12$ skeletal muscle cells, similar changes to those in our study were observed. Incubation with pal- mitate reduced insulin-stimulated glycogen synthesis as well as GSK-3- and Akt phosphorylation without having any effect on IRS-1 tyrosine phosphorylation and PI3K activity in IRS-1 immunoprecipitates [10].

The observation that TGRLs impair Akt- and GSK-3 phosphorylation while having no effect on IRS-1 tyrosine phosphorylation and PI3K activity indicates that there is no global effect of TGRLs on cell function and cell viability, a notion that is further supported by consistent LDH levels in the incubation media and by our experiments using DAPI staining and trypan blue exclusion (detailed in the Materials and methods section).

The IMCL content, which in many [1-4] but not all studies $[45,46]$ has been shown to be increased in insulin resistance, was also one focus of our experiments. The effects of TGRLs on insulin signalling and glucose homeostasis followed a time-dependent fashion. Hand in hand with these observations, accumulation of IMCLs progressed with incubation time, suggesting that IMCL accumulation is an inherent component of TGRL-induced insulin resistance in our cell culture system complementing the other features of insulin resistance.

After establishing that TGRLs lead to impaired glucose metabolism, insulin signalling and to an accumulation of IMCLs in L6 skeletal muscle cells, we wished to find out what major component of the lipoprotein particles exerts the observed effects. The major chemical component of TGRLs is the triglyceride fraction. Accordingly, we performed experiments with highly purified Intralipid triglyceride-rich micelles. Incubation with Intralipid did not induce a reduction of glycogen synthesis, however, in contrast to incubation with TGRLs, until there was an incubation period of $16 \mathrm{~h}$, a time period necessary to also attain IMCL accumulation, supporting the conclusions from the experiments with TGRLs regarding a close association between reduction of glycogen synthesis and accumulation of IMCLs in our system. Moreover, these data suggest that triglycerides, even if not assembled in native lipoproteins, are capable of causing comparable effects to native TGRLs.

However, the sharply contrasting time courses on glycogen synthesis, and IMCL accumulation with a continuous monotonous effect of TGRLs over time and the lack of such an effect until $16 \mathrm{~h}$ of Intralipid incubation suggest a different cellular uptake mechanism. For the uptake of TGRLs, our RAP experiments suggest a receptor-mediated process involving members of the LDL receptor family.

One issue deserving discussion, in our opinion, relates to a widely accepted view of TGRL metabolism, according to which TGRLs are hydrolysed by LPL with TGRL remnants going to the liver and the resulting NEFAs being taken up by various tissues including skeletal muscle. According to this view, TGRLs do not bind as intact lipoprotein particles to their respective receptors on extrahepatic cells like skeletal muscle cells. However, there is substantial evidence that TGRLs are not solely catabolised in the liver, but are taken up also by other tissues. In fact, chylomicron remnant uptake by the liver ranges, in various studies, from $80 \%$ down to $20 \%[47,48]$. 
Moreover, there is evidence for extrahepatic whole-particle uptake of intact chylomicrons and their remnants. In a series of studies with rabbits and rats, it has been shown that chylomicrons are able to penetrate arteries as efficiently as smaller macromolecules, including LDL, HDL and albu$\min [20,21,23,49,50]$. Whole-VLDL-particle uptake has also been demonstrated in mice, whereby whole-particle lipoprotein uptake in muscle increases by transgenic expression of catalytically inactive LPL in the presence of active LPL [51, 52]. A receptor-independent process [53], further characterised as endothelial transcytosis [54], has been proposed to represent the molecular mechanism of chylomicron uptake. For humans, there is also evidence for whole-lipoprotein-particle uptake [24, 19]; based on results with arterio-venous concentration differences of lipoprotein particle constituents, Karpe et al. hypothesised that skeletal muscle and adipose tissue are likely to be of importance for removal of chylomicron remnant particles [19]. Therefore, we believe that our observations with TGRLs are of biological relevance.

Finally, we would like to comment on how our data fit the published results on the effect of NEFAs on insulin sensitivity. A large number of reports on NEFAs including various experimental settings ranging from cell culture to studies in humans showed that NEFAs cause insulin resistance. We would like to emphasise that our in vitro data do not contradict the large body of evidence for the effect of NEFAs on insulin sensitivity but indicate that, in addition to NEFAs, important biological effects regarding insulin resistance can also be exerted by intact TGRL particles. The notion that in our experimental system, the observed effects are solely due to intact TGRL particles, not to NEFAs present in the incubation media, is supported by our observation that NEFA levels in the media did not increase with lipoprotein incubations and that NEFA levels in the TGRLcontaining media were equal to the NEFA levels in the incubation media with no lipoproteins present. Consistent with NEFA-independent TGRL-particle-induced effects, our experiment with orlistat demonstrated that co-incubation of TGRLs with this potent lipase inhibitor did not alter TGRL-induced impairment of glycogen synthesis, whereas co-incubation with RAP, inhibiting TGRL interaction with members of the LDL receptor family, reversed TGRLinduced effects.

In summary, we show for the first time that TGRLs, a lipoprotein fraction accumulating in the fasting and even more severely in the postprandial phase of insulin-resistant and diabetic subjects, are capable of causing insulin resistance as evidenced by an impairment of insulin-induced glycogen synthesis, glycogen synthase activity, glucose uptake and several insulin signalling steps. Our results complement those on lipoprotein-induced beta cell dysfunction [18] to suggest that changes in plasma lipoproteins observed in type 2 diabetes may not only be a consequence of this disease but also a cause of it.
Acknowledgements This study was supported by a grant from the Austrian Science Fund (FWF): P15951-B07 to M. T. Pedrini. We are grateful to Karin Salzmann for excellent technical assistance and to Dr Georg Kemmler for assistance with statistical analyses.

\section{References}

1. Hegarty BD, Furler SM, Ye J, Cooney GJ, Kraegen EW (2003) The role of intramuscular lipid in insulin resistance. Acta Physiol Scand 178:373-383

2. Pan DA, Lillioja S, Kriketos AD et al (1997) Skeletal muscle triglyceride levels are inversely related to insulin action. Diabetes 46:983-988

3. Perseghin G, Scifo P, De Cobelli F et al (1999) Intramyocellular triglyceride content is a determinant of in vivo insulin resistance in humans: a $1 \mathrm{H}-13 \mathrm{C}$ nuclear magnetic resonance spectroscopy assessment in offspring of type 2 diabetic parents. Diabetes 48:1600-1606

4. Boden G, Lebed B, Schatz M, Homko C, Lemieux S (2001) Effects of acute changes of plasma free fatty acids on intramyocellular fat content and insulin resistance in healthy subjects. Diabetes 50:1612-1617

5. Boden G, Jadali F, White J et al (1991) Effects of fat on insulinstimulated carbohydrate metabolism in normal men. J Clin Invest 88:960-966

6. Kruszynska YT, Worrall DS, Ofrecio J, Frias JP, Macaraeg G, Olefsky JM (2002) Fatty acid-induced insulin resistance: decreased muscle PI3K activation but unchanged Akt phosphorylation. J Clin Endocrinol Metab 87:226-234

7. Griffin ME, Marcucci MJ, Cline GW et al (1999) Free fatty acid-induced insulin resistance is associated with activation of protein kinase $\mathrm{C}$ theta and alterations in the insulin signaling cascade. Diabetes 48:1270-1274

8. Magnan C, Gilbert M, Kahn BB (1996) Chronic free fatty acid infusion in rats results in insulin resistance but no alteration in insulin-responsive glucose transporter levels in skeletal muscle. Lipids 31:1141-1149

9. Goudriaan JR, Dahlmans VE, Teusink B et al (2003) CD36 deficiency increases insulin sensitivity in muscle, but induces insulin resistance in the liver in mice. J Lipid Res 44:2270-2277

10. Schmitz-Peiffer C, Craig DL, Biden TJ (1999) Ceramide generation is sufficient to account for the inhibition of the insulinstimulated $\mathrm{PKB}$ pathway in $\mathrm{C} 2 \mathrm{C} 12$ skeletal muscle cells pretreated with palmitate. J Biol Chem 274: 24202-24210

11. Hunnicutt JW, Hardy RW, Williford J, McDonald JM (1994) Saturated fatty acid-induced insulin resistance in rat adipocytes. Diabetes 43: $540-545$

12. Thompson AL, Lim-Fraser MY, Kraegen EW, Cooney GJ (2000) Effects of individual fatty acids on glucose uptake and glycogen synthesis in soleus muscle in vitro. Am J Physiol Endocrinol Metab 279: 577-584

13. Usui I, Takata Y, Imamura T et al (1997) Fatty acid induced insulin resistance in rat-1 fibroblasts overexpressing human insulin receptors: impaired insulin-stimulated mitogen-activated protein kinase activity. Diabetologia 40:894-901

14. Shimabukuro M, Zhou YT, Levi M, Unger RH (1998) Fatty acid-induced beta cell apoptosis: a link between obesity and diabetes. Proc Natl Acad Sci USA 95:2498-2502

15. Lee Y, Hirose H, Ohneda M, Johnson JH, McGarry JD, Unger RH (1994) Beta-cell lipotoxicity in the pathogenesis of noninsulin-dependent diabetes mellitus of obese rats: impairment in adipocyte-beta-cell relationships. Proc Natl Acad Sci USA 91: 10878-10882

16. Lupi R, Dotta F, Marselli L et al (2002) Prolonged exposure to free fatty acids has cytostatic and pro-apoptotic effects on human pancreatic islets: evidence that beta-cell death is caspase mediated, partially dependent on ceramide pathway, and Bcl-2 regulated. Diabetes 51:1437-1442

17. Deeney JT, Prentki M, Corkey BE (2000) Metabolic control of beta-cell function. Semin Cell Dev Biol 11:267-275 
18. Roehrich ME, Mooser V, Lenain V et al (2003) Insulin-secreting beta-cell dysfunction induced by human lipoproteins. J Biol Chem 278:18368-18375

19. Karpe F, Humphreys SM, Samra JS, Summers LK, Frayn KN (1997) Clearance of lipoprotein remnant particles in adipose tissue and muscle in humans. J Lipid Res 38:2335-2343

20. Proctor SD, Mamo JC (1996) Arterial fatty lesions have increased uptake of chylomicron remnants but not low-density lipoproteins. Coron Artery Dis 7:239-245

21. Proctor SD, Mamo JC (1998) Retention of fluorescent-labelled chylomicron remnants within the intima of the arterial wallevidence that plaque cholesterol may be derived from postprandial lipoproteins. Eur J Clin Invest 28: 497-503

22. Proctor SD, Pabla CK, Mamo JC (2000) Arterial intimal retention of pro-atherogenic lipoproteins in insulin deficient rabbits and rats. Atherosclerosis 149:315-322

23. Daugherty A, Lange LG, Sobel BE, Schonfeld G (1985) Aortic accumulation and plasma clearance of beta-VLDL and HDL: effects of diet-induced hypercholesterolemia in rabbits. J Lipid Res 26:955-963

24. Rapp JH, Lespine A, Hamilton RL et al (1994) Triglyceriderich lipoproteins isolated by selected-affinity anti-apolipoprotein B immunosorption from human atherosclerotic plaque. Arterioscler Thromb 14: 1767-1774

25. Nordestgaard BG, Wootton R, Lewis B (1995) Selective retention of VLDL, IDL, and LDL in the arterial intima of genetically hyperlipidemic rabbits in vivo. Molecular size as a determinant of fractional loss from the intima-inner media. Arterioscler Thromb Vasc Biol 15:534-542

26. Patsch JR, Karlin JB, Scott LW, Smith LC, Gotto AM Jr (1983) Inverse relationship between blood levels of high density lipoprotein subfraction 2 and magnitude of postprandial lipemia. Proc Natl Acad Sci USA 80: 1449-1453

27. Patsch W, Patsch JR, Kostner GM, Sailer S, Braunsteiner H (1978) Isolation of subfractions of human very low density lipoproteins by zonal ultracentrifugation. J Biol Chem 253: 4911-4915

28. Patsch JR, Patsch W (1986) Zonal ultracentrifugation. Methods Enzymol 129: 3-26

29. Patsch JR, Prasad S, Gotto AM Jr, Bengtsson-Olivecrona G (1984) Postprandial lipemia. A key for the conversion of high density lipoprotein 2 into high density lipoprotein 3 by hepatic lipase. J Clin Invest 74:2017-2023

30. Keppler D, Decker K (1974) Glycogen. In: Bergmeyer H, Grass1 $\mathrm{M}$ and Bergmeyer J (eds) Methods of enzymatic analysis, 3rd edn. Verlag Chemie International, Deerfield Beach, FL, USA, pp 1127-1131

31. Krebs M, Stingl H, Nowotny P et al (2000) Prevention of in vitro lipolysis by tetrahydrolipstatin. Clin Chem 46:950-954

32. Thomas JA, Schlender KK, Larner J (1968) A rapid filter paper assay for UDPglucose-glycogen glucosyltransferase, including an improved biosynthesis of UDP-14C-glucose. Anal Biochem 25:486-499

33. Michael LF, Wu Z, Cheatham RB et al (2001) Restoration of insulin-sensitive glucose transporter (GLUT4) gene expression in muscle cells by the transcriptional coactivator PGC-1. Proc Natl Acad Sci USA 98: 3820-3825

34. Koopman R, Schaart G, Hesselink MK (2001) Optimisation of oil red O staining permits combination with immunofluorescence and automated quantification of lipids. Histochem Cell Biol 116: 63-68

35. Canny J (1986) A computational approach to edge detection. IEEE transactions on pattern analysis and machine intelligence PAMI-8: 679-698

36. Shulman GI, Rothman DL, Jue T, Stein P, DeFronzo RA, Shulman RG (1990) Quantitation of muscle glycogen synthesis in normal subjects and subjects with non-insulin-dependent diabetes by $13 \mathrm{C}$ nuclear magnetic resonance spectroscopy. $\mathrm{N}$ Engl J Med 322: 223-228

37. Sun XJ, Rothenberg P, Kahn CR et al (1991) Structure of the insulin receptor substrate IRS-1 defines a unique signal transduction protein. Nature 352: 73-77
38. Hara K, Yonezawa K, Sakaue H et al (1994) 1-Phosphatidylinositol 3-kinase activity is required for insulin-stimulated glucose transport but not for RAS activation in $\mathrm{CHO}$ cells. Proc Natl Acad Sci USA 91: 7415-7419

39. Cross DA, Alessi DR, Cohen P, Andjelkovich M, Hemmings BA (1995) Inhibition of glycogen synthase kinase-3 by insulin mediated by protein kinase B. Nature 378:785-789

40. Welsh GI, Proud CG (1993) Glycogen synthase kinase-3 is rapidly inactivated in response to insulin and phosphorylates eukaryotic initiation factor eIF-2B. Biochem J 294:625-629

41. Huff MW, Miller DB, Wolfe BM, Connelly PW, Sawyez CG (1997) Uptake of hypertriglyceridemic very low density lipoproteins and their remnants by HepG2 cells: the role of lipoprotein lipase, hepatic triglyceride lipase, and cell surface proteoglycans. J Lipid Res 38:1318-1333

42. Herz J, Goldstein JL, Strickland DK, Ho YK, Brown MS (1991) 39-kDa protein modulates binding of ligands to low density lipoprotein receptor-related protein/alpha 2-macroglobulin receptor. J Biol Chem 266:21232-21238

43. Kim YB, Nikoulina SE, Ciaraldi TP, Henry RR, Kahn BB (1999) Normal insulin-dependent activation of Akt/protein kinase $\mathrm{B}$, with diminished activation of phosphoinositide 3-kinase, in muscle in type 2 diabetes. J Clin Invest 104:733-741

44. Krook A, Roth RA, Jiang XJ, Zierath JR, Wallberg-Henriksson $\mathrm{H}$ (1998) Insulin-stimulated Akt kinase activity is reduced in skeletal muscle from NIDDM subjects. Diabetes 47:1281-1286

45. Voshol PJ, Jong MC, Dahlmans VE et al (2001) In musclespecific lipoprotein lipase-overexpressing mice, muscle triglyceride content is increased without inhibition of insulin-stimulated whole-body and muscle-specific glucose uptake. Diabetes 50: 2585-2590

46. Thamer C, Machann J, Bachmann O et al (2003) Intramyocellular lipids: anthropometric determinants and relationships with maximal aerobic capacity and insulin sensitivity. J Clin Endocrinol Metab 88:1785-1791

47. Hussain MM, Mahley RW, Boyles JK, Fainaru M, Brecht WJ, Lindquist PA (1989) Chylomicron-chylomicron remnant clearance by liver and bone marrow in rabbits. Factors that modify tissue-specific uptake. J Biol Chem 264:9571-9582

48. Hultin M, Carneheim C, Rosenqvist K, Olivecrona T (1995) Intravenous lipid emulsions: removal mechanisms as compared to chylomicrons. J Lipid Res 36:2174-2184

49. Proctor SD, Mamo JC (2003) Intimal retention of cholesterol derived from apolipoprotein B100- and apolipoprotein B48containing lipoproteins in carotid arteries of watanabe heritable hyperlipidemic rabbits. Arterioscler Thromb Vasc Biol 23: $1595-1600$

50. Mamo JC, Wheeler JR (1994) Chylomicrons or their remnants penetrate rabbit thoracic aorta as efficiently as do smaller macromolecules, including low-density lipoprotein, high-density lipoprotein, and albumin. Coron Artery Dis 5:695-705

51. Merkel M, Heeren J, Dudeck W et al (2002) Inactive lipoprotein lipase (LPL) alone increases selective cholesterol ester uptake in vivo, whereas in the presence of active LPL it also increases triglyceride hydrolysis and whole particle lipoprotein uptake. J Biol Chem 277:7405-7411

52. Merkel M, Kako Y, Radner H et al (1998) Catalytically inactive lipoprotein lipase expression in muscle of transgenic mice increases very low density lipoprotein uptake: direct evidence that lipoprotein lipase bridging occurs in vivo. Proc Natl Acad Sci USA 95:13841-13846

53. Nordestgaard BG, Tybjaerg-Hansen A (1992) IDL, VLDL, chylomicrons and atherosclerosis. Eur J Epidemiol 8 [Suppl 1]: 92-98

54. Simionescu N, Simionescu M (1991) Cellular interactions of lipoproteins with the vascular endothelium: endocytosis and transcytosis. Targeted Diagn Ther 5:45-95 